\title{
Globalization: implications for immigrants and refugees
}

\author{
Anthony H. Richmond
}

\begin{abstract}
Globalization is not a new process. It is an acceleration of changes induced by the post-industrial revolution in transport and communication. The rapid growth of population in less developed countries combines with a reduction in barriers to migration from formerly authoritarian regimes to induce mobility. Economic inequality combines with demographic pressures and environmental crises to generate ethnic conflict and terrorist threats. Wealthier countries are placing restrictions on the admission of those seeking to improve their economic prospects and/or to escape persecution. Despite the number of asylum seekers in Europe and North America, African and Asian countries bear the greatest burden of refugees. Temporary migration, business travel and tourism have added to the numbers crossing state boundaries, making effective control difficult. It is concluded that recommendations made by the Commission on Global Governance should be implemented without delay.
\end{abstract}

Keywords: globalization; migration; refugees; ethnic; conflict; governance.

The term 'globalization' entered the vernacular over a decade ago. It is now used loosely to describe almost any economic or social change that affects more than one country. However, the existence of world capitalist system is not new. It can be traced as far back as the sixteenth century (Wallerstein 1974). Large-scale international migration has a similarly long history. There was mass migration from Europe to the 'New World' in the eighteenth and nineteenth centuries. The slave trade from Africa, and indentured labour from the East Indies, were early examples of globalization in labour markets. There was further migration to North America from Asia at the time of the 'gold rush'. The USA passed the Chinese Exclusion Act in 1889. Canada imposed head taxes on Chinese immigrants from 1885 onward, and virtually excluded them between 1923 and 1961. There was relatively free movement within Europe until early in the twentieth century. The first legislation restricting immigration to Britain was the Alien's Act, 1905. Passports were not 
introduced until World War I. Although earlier waves of migration resulted in a substantial net loss of population from European countries, return migration and seasonal movements were not unknown.

What is new in this age of globalization is the acceleration of the rate of change induced by the post-industrial revolution. It is the rapid speed of air transportation, and the instantaneous electronic transfer of information and capital, which have made globalization a reality. It has given rise to what Anthony Giddens (1985) called 'time-space distanciation', that is to say the experiential compression of time and space. As Manuel Castells (1996) has documented in his treatise on 'The Information Age', the global system is a network society made up of linkages between production, power and experience. These networks 'construct a culture of virtuality in the global flows which transcend time and space' (Castells 1998, p.350). In turn, these trends are related to the cultural innovation and relativity which has come to be understood as 'post-modernism', or as Giddens calls it 'high modernity' and 'post-traditionalism'. But Giddens also notes that 'Globalization is not a single process but a complex mixture of processes, which often act in contradictory ways, producing conflicts, disjunctures and new forms of inequality' (Giddens 1994, p. 5).

The rise of ethnic nationalism at the end of the twentieth century was associated with the disintegration of supranational states and the emergence of a post-industrial global economy. Earlier discussions of postindustrialism did not anticipate the collapse of the Soviet Union. However, it was suggested that reactionary insurgent movements, identified with ideologies of capitalism, communism and religious orthodoxies, would perpetuate ethnic conflicts in the transitional stages of transformation from pre-industrial, and industrial societies, to a postindustrial global system characterized by high rates of emigration and return (Richmond 1969, 1984).

The failure of communist regimes in the former Soviet Union, Yugoslavia and other countries of eastern Europe, together with rapid changes occurring in mainland China and other parts of Asia, Africa and Latin America, have added new dimensions to the changes already induced by technology. Once nearly impermeable borders are now open to cultural influences; people can migrate and/or engage in political protest, more than ever before. Formerly authoritarian regimes are challenged by these new freedoms. Culturally diverse, but centrally governed, states are disintegrating in the face of civil war, ethnic cleansing and irredentist movements. The latter are designed to re-unite ethnoreligious groups previously separated by arbitrary state frontiers. New forms of nationalism have emerged, some extremely violent. The result is waves of reactive, or forced, migration. These are added to the existing flows of proactive, or mainly economically motivated movements of population. In fact, there is no clear-cut distinction between 'proactive' 
and 'reactive' migrants but, rather, a continuum between those who have some freedom of choice whether, when and where to move, and those who are impelled by circumstances beyond their control (Richmond 1993). Political, economic and social factors combine to propel and expel people. Some are internally displaced while others are obliged to cross borders. Attempts to restrict the flow of so-called 'economic refugees' and others seeking asylum from political persecution have led to a form of 'global apartheid' (Richmond 1994).

All these developments have brought about a fundamental shift in the balance of power within the world system. New regional alliances have formed, transnational corporations have acquired even greater wealth and influence, and the 'information superhighway' is in process of transforming social networks, human consciousness and the perception of individual and collective identity. Within the former Soviet Union, nationalism, secessionist movements and inter-ethnic tensions have exploded. The Baltic region, Ukraine, the Caucasus and the Muslim republics all experienced a resurgence of nationalism, leading either to independence, civil war, or both. As Castells (1997, pp. 68-69) notes:

Reduced to networks of primary identity and individual survival, Russian people, and the people of the ex-Soviet societies, will have to muddle through the reconstruction of their collective identity, in the midst of a world where the flows of power and money are trying to render piecemeal the emerging economic and social institutions before they come into being, in order to swallow them in their global networks.

In other words, the 'cold- turkey' transformation from communism to capitalism has left people feeling helpless and lost. The same could be said of the former Yugoslavia, and of other countries in Africa, Asia and the Americas, experiencing major economic, political and social convulsions (Van Horne 1997; Siddique 2001). Both centrifugal and centripetal forces are at work. Linguistic, religious and ethnic minorities seek to achieve sovereignty either by negotiation, or by force. At the same time existing states relinquish powers to supranational agencies. These agencies range from managed trade agreements such as the World Trade Organization and NAFTA, to closer economic and political communities, such as the European Union, together with mutual defence alliances, on the lines of NATO, and the CSCE (Conference on Security and Cooperation in Europe). In addition, there are extensive networks of voluntary organizations (NGOs) functioning within the global system.

The United Nations Organization itself is currently at the centre of a complex web of competing interests. While called upon to make and keep the peace in various parts of the world, it finds itself impotent in 
the face of a disseminated capacity to use coercion. Unlike the multinational states of the past, the UN is not a 'supreme coercive power', able to impose its will by indoctrinating a single ideology, or defending and extending its borders against external enemies. Instead of a 'Cold War' between two major super-powers, representing the opposing ideologies of 'capitalism' and 'communism', the USA has emerged, at least for the time being, as the only major super-power. It is reluctant to become directly involved in the ethnic conflicts elsewhere in the world, unless its own direct interests are involved. The end of the 'Cold War' has led to an erosion, and necessary re-definition of, American national interests which are now even more closely tied to commerce (Huntington 1996, p.37).

The global system is in a state of transition. Elements of the previous forms of social integration are still present. However, partly as a reaction against the threatening nature of rapid change, and the insecurity generated, people are reverting to old sources of collective identity and moral support, including shared language, religion and territorial attachment. Relatively benign forms of cultural nationalism have become politicized, and merged with more aggressive types (Cozic et al. 1994). New independence movements have arisen on all continents. In turn, they give rise to internally displaced persons, as well as refugee movements. Holy wars, nationalist wars, ethnic conflicts, genocidal threats, and terrorist activities combine to create profound instability. They are facilitated by a global arms market which is a major source of profit to transnational corporations, as well as to clandestine arms dealers and mercenary armies (Kaldor 1999). The consequences are evident in Afghanistan, the Horn of Africa, Rwanda, Bosnia, Kosovo and, more recently, Macedonia, Chechnia and East Timor. Arguably, the post cold war global regime uses 'humanitarian intervention' as an ideology to justify the use of military force in such cases. It uses 'the language of human rights to legitimise a range of dubious practises' (Chimni 2000, p.2).

\section{Demographic trends 1}

When the consequences of over-population, numerous natural disasters, and famine are added to the equation, the potential for change, and shifts in power, in the global system are seen by many people in wealthier countries, as extremely threatening. However, the dangers consequent upon population growth and migration should not be exaggerated. The rates of population growth in the world are slowing, and will continue to decline as standards of living improve. The world's population reached an estimated six billion in the year 2000. If present trends continue (and despite the spread of AIDS) it could reach nine billion by the year 2050 (OECD 1999) (see Table 1). Without immigration, the 
populations of the more developed countries, in Europe and North America, will actually decline over this period, due to ageing and low fertility.

\section{Globalization and immigration}

In the context of a modern world system experiencing globalization the distinction, which existed through most of the twentieth century, between population 'sending' and 'receiving' countries, is no longer useful. The USA, Canada, Australia, New Zealand and some countries in Latin America were usually considered countries of immigration. They actively encouraged inflows of selected people. Almost all others were, formerly, either countries of emigration, or were not importing or exporting people on a measurable scale. This is no longer the case. Almost all countries (particularly the economically developed ones) experience heavy traffic across borders by land, sea and air. Globalization has facilitated transport and communications, as well as manufacturing, trade, services and financial transactions, particularly as the process of globalization accelerated in the last two decades. Business travel and tourism are major components of these population movements. For example Canada, with a population of 31 million people, actually experiences close to 50 million entries by non-resident travellers annually. Of these, approximately four million are from countries other than the USA. They include tourists, business travellers, those on Minister's Permits, and temporary employment visas, students, asylum applicants,as well as landed immigrants. The latter constituted only 200,000 of the approximately 50 million entrants. Similarly, the USA receives approximately 97 million international travellers annually, by air alone. To these must be added all those who arrive and depart by

Table 1. Population projections for world regions, years 2000 to 2050

\begin{tabular}{lcclc}
\hline & Year 2000 & Year 2050 \\
\hline REGION & Millions & per cent & Millions & per cent \\
\hline WORLD & 6,055, & 100.0 & 8,909, & 100.0 \\
DEVELOPED & 1,188, & 19.6 & 1,155, & 13.0 \\
DEVELOPING & 4,867, & 80.4 & 7,754, & 87.0 \\
AFRICA & 784, & 12.9 & 1,766, & 19.8 \\
ASIA & 3,683, & 60.9 & 5,268, & 59.2 \\
CENTRAL & & & & \\
AMERICA & 519, & 8.6 & 809, & 9.1 \\
NORTH AMERICA & 310, & 5.1 & 392, & 4.4 \\
EUROPE & 729, & 12.0 & 628, & 7.0 \\
OCEANA & 30, & 0.5 & 46, & 0.5 \\
\hline
\end{tabular}

Source: UN, World Population Prospects, 1998. (Medium projections; excludes net migration) 
land and sea, particularly the vast number of trucks and cars crossing the Canadian and Mexican borders every day. There is similar heavy traffic across borders in Europe and between Europe and Britain.

There is periodic concern regarding the so-called 'brain drain' from Britain, Canada, and other countries. In reality there is an exchange of highly qualified people between most advanced industrial countries. There is a global labour market for professionals, managers, information technology experts, and scientists in all fields. However, there are still licensing and professional association barriers to the full recognition of qualifications obtained abroad. The knowledge and skills of highly qualified immigrants (and refugees) are seriously under-utilized in many countries. The situation is not new and has been well known to Canadian immigration officials for nearly forty years, without any satisfactory resolution of the problem.(Richmond 1967; Cumming 1989).

Former countries of 'emigration', as well as traditional 'immigration' countries, are now significant receivers of both proactive and reactive migrants. Net gains and losses of population, between countries and regions, may vary over time, and have differential demographic impacts, but the scale of population movement has greatly accelerated. Low birth rates in Britain and other European countries make net inward movements of population necessary to avert population decline in the future. Migration influences the sex and age distributions, as well as ethnic composition, urbanization and educational levels of sending and receiving countries alike. Countries of Europe, parts of Asia, Oceana and the whole of the Americas, including the Caribbean, are now part of a global system of population movement by land, sea and air. South Africa also participates, although the rest of Africa is largely excluded. States are no longer able to control their borders effectively, although they continue to try using methods of surveillance, and interdiction, that are becoming more and more draconian. In reality, even the most authoritarian police state could not prevent some determined individuals from escaping to freedom, as was evident during the 'Cold War' period. However, this has not prevented current efforts to combat organized 'people smuggling', using the same methods that have failed to prevent the import of illegal drugs.

The distinction between temporary and permanent migration is no longer meaningful. Globalization has facilitated world-wide network linkages with friends and families in the former country,and with the international labour market. Transilience, understood as the ability to move from one country and culture to another and back again, was once limited to highly qualified professional and managerial classes (Richmond 1969). It is now characteristic of many occupations ranging from seasonal farm labour, through domestic service, construction workers and oilrig operators, to doctors, nurses, teachers, scientists, managers and many others. More people work in 'foreign' countries on 
temporary visas and work permits, than are admitted as 'permanent' residents. In practice, the latter are often as mobile and transient as those labelled 'temporary'. An estimated 120 million people are working outside their country of birth, excluding those who have emigrated 'permanently' to other countries. Many more countries have become both senders and receivers of international labour migrants. An ILO analysis of migration patterns in 152 countries showed that, between 1970 and 1990 , the number of countries classified as major receivers of labour immigrants rose from thirty-nine to sixty-seven. Over the same twenty years, the number of countries designated as major international labour suppliers rose from twenty-nine to fifty-five. (Stalker 2000). It is even suggested that, when legal and illegal movements of population are taken into account, international migration 'can be considered as the component parts of a world-wide industry, consisting of a series of businesses where it is possible to identify vested interests which seek to manage and develop migration flows' (Salt 2001, p.106).

Even refugees and their descendants may return to their former country in due course, or choose to move elsewhere. Others migrate or re-migrate on retirement. Annual 'quotas' or 'targets' for immigration are not practical, or enforceable. Periodic amnesties for 'overstayers', 'illegals', and backlogged asylum applicants have become routine. Zygmunt Bauman makes a distinction between 'tourists' and 'vagabonds', using tourist to mean all categories of legitimate travellers and 'frequent flyers'. He states:

What is acclaimed today as "globalization" is geared to the tourists" dreams and desires. Its second effect - a side effect, but an unavoidable one - is the transformation of many others into vagabonds. Vagabonds are travellers refused the right to turn into tourists. They are allowed neither to stay put (there is no site guaranteeing permanence, the end to undesirable mobility) nor search for a better place to be (Bauman 1998, p. 93).

In a study of immigration and what he calls the 'New World Worker', economist Nigel Harris argued the case for removing all barriers to immigration in the interests of a global free market economy. $\mathrm{He}$ foresees a situation in which, as transport grows faster, people will live in one place and work in another, as indeed city commuters do already. 'At an extreme, the entire labour force might live outside the country' (Harris 1995, p. 225). He instances the software programmers who are living in Bombay but, technically, work for firms in New York. If such a situation were to become the norm it would, indeed, be the logical outcome of 'time-space compression', taken to its ultimate conclusion. However, it is unlikely to become the norm, although it does indicate the revolutionary potential consequent upon the new technologies. 
Distance education is one sphere where new information technologies make remote control feasible; but other services, such as health care, domestic help, and the cleaning and maintenance of buildings and public utilities, all require workers to be present in a particular location. There are physical limitations to the impact of time-space compression on social systems. Food is imported from afar, and many goods manufactured abroad, in cheap labour markets. Financial transactions, computer programming, architectural and engineering designing, data processing and TV entertainment can all be provided from a distance. In an emergency, expert advice may be transmitted to a surgeon, or other specialist, from a distance, but someone must carry out the operation on the spot. If you want your appendix taken out, the roads swept, your hair cut, your home or office cleaned, your children looked after, you will need someone physically close who will do it. Modern communications technology will not eliminate the need for services, or the phenomenon of migration, but it will undoubtedly revolutionize the way services are provided, and by whom. Proactive economic migration is the lubricant that keeps the wheels of the global capitalist system turning.

Globalization, whether driven by market forces or technological innovation, will not eradicate poverty, reduce inequality or prevent civil wars. The logic of the global capitalist system requires relatively free movement of labour. Free trade, currency unions, transnational corporate investment, combined with the rapid movement of capital between global financial institutions, make labour mobility imperative. Manufacturing moves to the cheapest labour markets, and communications workers function from any computer, wherever located; but personal service occupations, management, construction, agriculture and resource exploitation depend upon labour mobility. What Saskia Sassen calls 'global cities', such as London, New York, Tokyo and Toronto, attract both the highest and lowest income earners. Among the latter are the women from Third World countries recruited as housekeepers, nannies, practical nurses and office cleaners. Sassen describes 'a new geography of centrality and marginality' in which inequality is greatly increased. She states

This devalorization of growing sectors of the economy has been embedded in a massive demographic transition toward a growing presence of women, African Americans and Third World immigrants in the urban workforce... Globalization is a process that generates contradictory spaces, characterized by contestation, internal differentiation, continuous border crossings. The global city is emblematic of this condition (Sassen 1998, pp. xxiv-xxxiv).

Eventually, gross inequalities within and between countries and regions, would be reduced by free movement of labour, but this will 
likely be at the expense of high living standards of manual and service workers in the wealthier countries. In a global economy, based on unregulated free market principles, the rich are bound to get richer, and the poor relatively poorer. Politically, such a system becomes even more unstable than the world in which we live at present. This is why free movement across borders by people from the Third World is resisted by governments, and unionized workers, in wealthy countries. Labour unions and individual employees feel threatened by the competition from cheap labour in other countries, as well as migrant workers in their own. Hence the rise of anti-immigrant sentiments and the growing support, in many countries, for neo-fascist parties demanding more restrictive immigration and asylum policies.

Some policy-makers favour what is called a 'root causes' approach to migration from developing countries. This would involve the encouragement of investment, and the promotion of education and training, in the Third World, in order to create more employment opportunities. These are manifestly desirable goals but, contrary to expectations, they would not reduce the propensity to migrate. On the contrary, better educated, qualified and experienced workers will take advantage of a global labour market to seek opportunities wherever they occur. Furthermore, remittances from relatives abroad are already, and will continue to be, an important source of income for many families living in Africa, Asia and other developing regions.

Realistically, barriers to free movement across borders between low and high income countries will likely persist. In all probability, they will be strengthened, in order to reduce competition for employment in wealthier regions. Politicians in more developed countries will feel compelled to protect the interests of their own constituents, by encouraging foreign investors to create employment. Free trade agreements, and currency unions with neighbouring states will include clauses designed to facilitate labour mobility, subject to professional recognition of qualifications, union agreements and social security reciprocity. However, such agreements will be conditional on peripheral borders of the region being more strictly controlled. Regional inclusiveness will spell the exclusion of others, unless the latter bring capital to invest, or exceptional qualifications in short supply. When the fear of 'people smuggling' by organized crime syndicates is added to the picture, reactionary measures will be taken to stem the flow of undocumented migrants. Organized crime links to money laundering, drug trafficking and arms dealing constitute the 'dark side' of globalization. In a report prepared for the International Organization for Migration [IOM], Bimal Ghosh stated 'Trends in the globalization of irregular migration are considerably reinforced by the emergence of a market for trafficked migrants ... including women and children' (Ghosh 1998, p. 69). He mentions exotic dancing, prostitution and sex tourism, where illegal 
immigrant women are forced into near slavery. The exploitation of undocumented workers, male and female, is widespread on all continents.

Unfortunately, there is a real danger that immigration controls, ostensibly designed to deal with organized crime and clandestine migration, will threaten human rights. Advanced technologies make monitoring and the detailed control of populations feasible. Passports and visas no longer facilitate movement between countries but are instruments of exclusion. When combined with finger-printing, voice prints, photoidentity cards, identification numbers, DNA tests, electronic tags, and surveillance cameras, they constitute a formidable armoury of control devices. At borders such measures may be augmented by electric fences, armed guards, helicopters, sniffer dogs and electronic sensors. Smuggling 'illegal' immigrants is a response to the pent-up demand created by immigration restrictions. Undocumented migrants may be subject to violence, body searches and/or prolonged incarceration.

Immigration officers combine with interpol and local police to enforce deportation orders which are sometimes executed with undue force, resulting in death, or injury, to the deportee. Families may be split when some members have residence rights and others do not. Legislation, passed in Britain in 1999, is designed to deter undocumented migrants and asylum seekers, punish the carriers, and penalize employers who take advantage of them. The new regulations are designed to harmonize' UK policies with those of other European countries. In February 2001, the British and Italian Prime Ministers announced new initiatives and closer collaboration to combat 'people trafficking' in the Balkan region (Blair and Amato 2001). Officially, these policies are described as a 'non-exodus' approach to emigration from developing countries. Canada is currently 'harmonizing' its regulations with those of the United States, in order to formulate a consistent regional policy. Ironically, Canadian citizens may be excluded,or subject to deportation from the USA, if they technically breach regulations that were originally designed to stem the flow of illegal migrants to the US from Mexico. There are similar efforts to co-ordinate immigration policies and border controls in Europe. There would be some merit in ensuring uniformity of treatment for aspiring immigrants and asylum seekers if the intention were to ensure the enforcement of ILO Conventions regarding the rights of migrant workers, and a generous interpretation of the UN Refugee Convention. In practice, this is not the case and controls have become stricter, with less concern for human rights.

\section{Refugees and asylum seekers}

At the same time as economically motivated proactive migration flows increase globally, political upheavals have generated ethnic conflicts and 
civil wars giving rise to a rapid growth in reactive migration to developed regions, including Europe and North America. Nevertheless, the main burden of support for victims of war, political persecution and forced displacement from other causes remains in the developing countries of the 'Third World' (UNHCR 2000).

Globalization has contributed to an exacerbation of existing inequalities in the distribution of the world's wealth and income (see Figure 1). Poverty and inequality, by themselves, are not necessarily causal factors in migration. Indeed, it is generally those who have money, or human capital, who are able to move most easily, whether internally or externally, legally or illegally. There are many causal factors, of both the push and pull variety, which contribute to proactive as well as reactive migration. Among them is environmental degradation, which frequently combines with famine and with political conflict, to induce mass migration (Homer-Dixon and Percival 1996; Homer-Dixon 1999). A multivariate model of this process is shown in Figure 2.

Demographic pressures in Africa, Asia and other low-income countries, combined with poverty and frustrated ambitions, have exacerbated ethnic tensions and civil conflicts. Although birth and death rates are declining, rates of population increase in many developing countries greatly exceed economic growth, and constitute a potential threat to environmental sustainability. Unfortunately, migration to more developed regions exacerbates environmental degradation, due to higher levels of resource consumption, which lead to air and water pollution,

Figure 1. Global inequality: GNP per capita Regional Differences, 1998

Source: World Bank Development Report, 2000; *HIGH INCOME includes

W. Europe, North America etc.

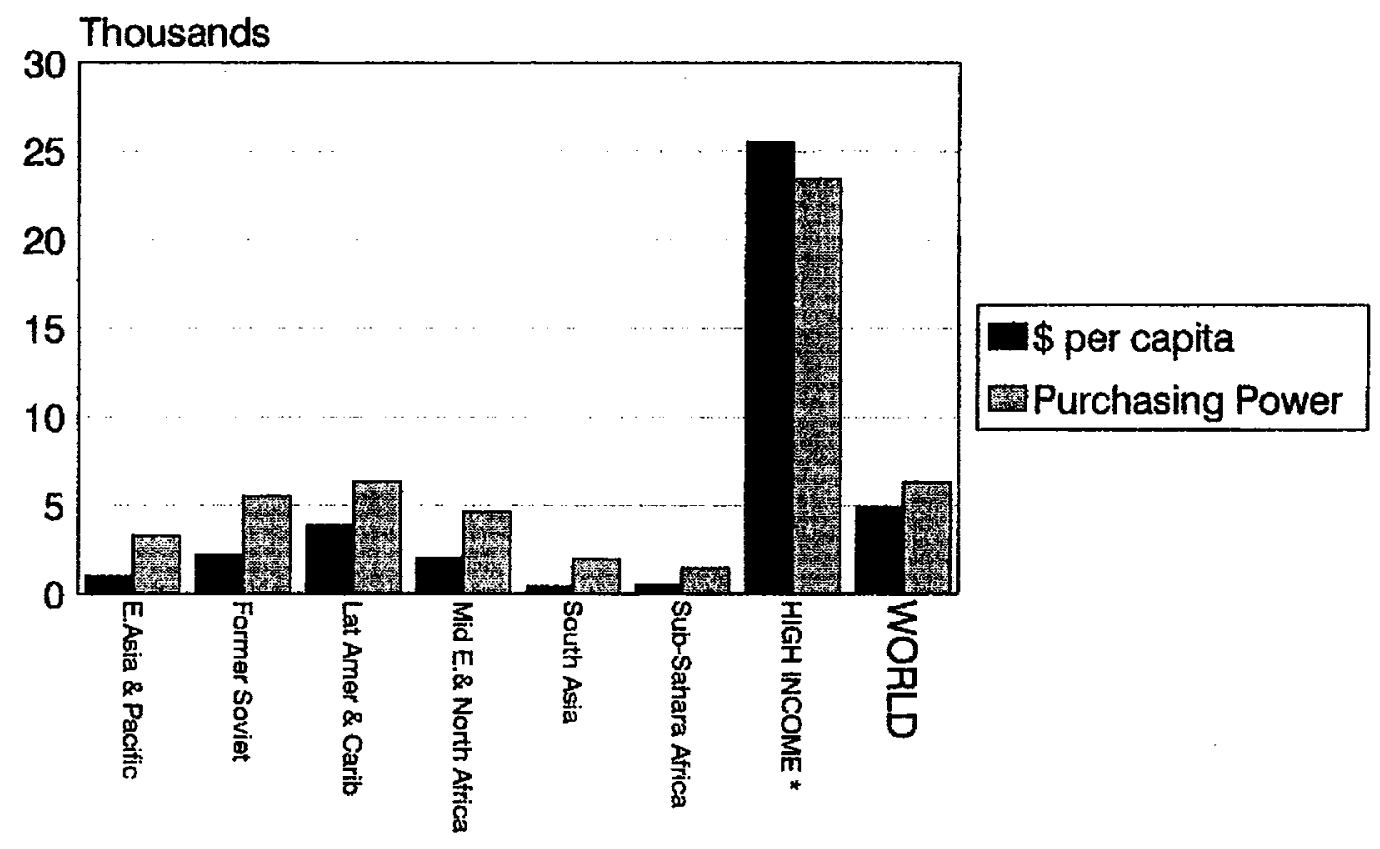


Figure 2. Environment and migration

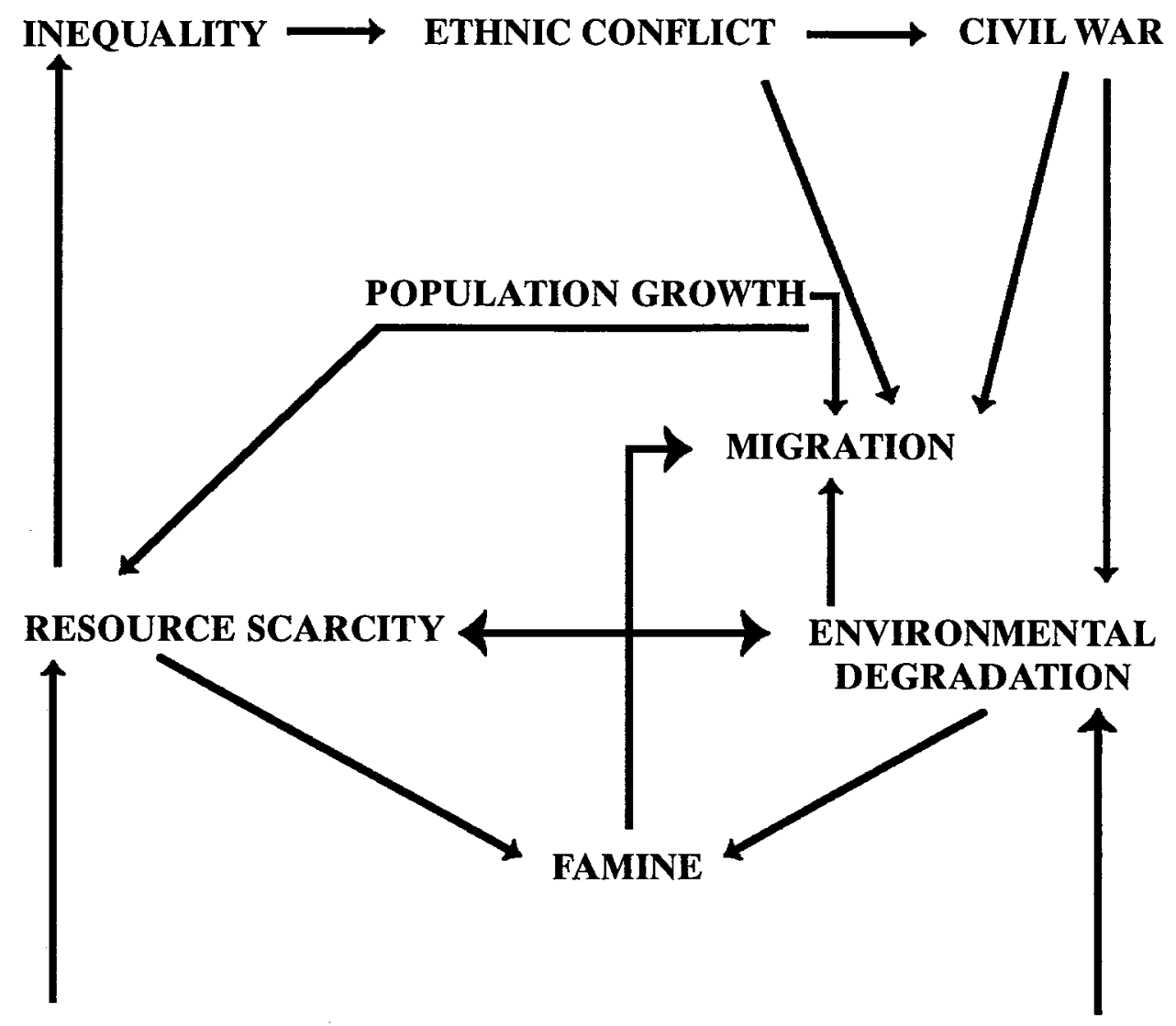

DROUGHTS EARTHQUAKES VOLCANIC ERUPTIONS POLLUTION FLOODS

soil erosion, etc. Competition for scarce resources including land, water and employment opportunities will add to existing ethnic rivalry and political tensions. As a consequence, there will be more internally displaced persons, religious pogroms and 'ethnic cleansing'.

Labelling asylum applicants, and others fleeing persecution and civil war, as 'really' just economic migrants is based on misunderstanding and prejudice. Unfortunately, the UN Convention on Refugees, signed in 1951 and amended in 1967, is anachronistic and needs to be replaced. Originally intended to meet the situation created during and after World War II, the Convention no longer addresses the crises that have occurred since the end of the 'Cold War'. Its interpretation varies widely from one jurisdiction to another. The distinction between persecution and systemic discrimination has become blurred. New international laws are needed that will protect all migrants, including contract workers, against discrimination, and facilitate temporary and longer term asylum and protection for those who face persecution in their own countries.

Western and northern countries are concerned about the number of 
asylum seekers and refugees reaching their shores. They have adopted non-entree policies and encouraged deportation and repatriation. The truth is that the vast majority of refugees are temporarily located in countries close to where the conflicts have occurred. The largest single source of refugees under the care of the UNHCR is Afghanistan, and the greatest numbers are located in Iran and Pakistan. Countries in Africa and Asia bear the greatest burden of refugee protection. Women (50.4 per cent) and children(15.2 per cent) together form the majority of those found in refugee camps, i.e. UNHCR-assisted refugees (UNHCR 1999, p. 32). The number of asylum seekers in Europe and North America rose in the early 1990s, and declined at the end of the decade partly due to the deterrent measures put in place. The majority of the world's refugees are still located in Africa and Asia, as shown in Table 2. At the end of the year 2000 , there were over two million refugees in Pakistan, 1.9 million in Iran and 2.3 million in countries of the Horn of Africa. There were over half a million in former Yugoslavian territories such as Bosnia. When returned refugees, the internally displaced and others of concern to the UNHCR are counted, there were 21.8 million people in refugee or similar crisis situations, with Third World countries bearing the greatest burden.

Whether border controls are maintained, relaxed, or strengthened there are policy implications arising from globalization, and consequent population mobility. Almost all countries have multiracial and multilingual populations, requiring policies that are designed to accommodate diversity and protect the rights of minorities. Globalization reinforces the need for a universal recognition of multicultural policies, and human rights enforcement. 'In the wake of the Cold War's configuration of the world into superpowers and satellites, the globe has become streaked with dissolving states, so-called terrorist acts aimed at achieving national liberation or recognition of territory, refugees from genocide, as well as the quieter, more individualized acts of racist and ethnic brutality and oppression that go on every day.' (Cornwell and Stodddard 2001, p.23). Given the postmodern trend towards fragmentation, we may be moving towards a system of wealthy metropolitan city-states engaged in global commerce, while their impoverished hinterlands war with each other. There could be a multiplicity of ethno-cultural conflicts in these economically deprived regions, but this does not rule out the possibility of a larger confrontation between major powers. Samuel Huntington (1996) argued that violent conflicts in the future will occur along cultural fault lines separating what he called 'civilizations'. By this he meant a grouping of people on the broadest level of cultural identity. He singled out the fault line between 'Western' and 'Islamic' civilizations as the most vulnerable, and likely to lead to a major power struggle. He envisaged a Confucian-Islamic alliance challenging Western interests and leading, eventually, to a paramount axis of 'the West and the Rest'. $\mathrm{He}$ 


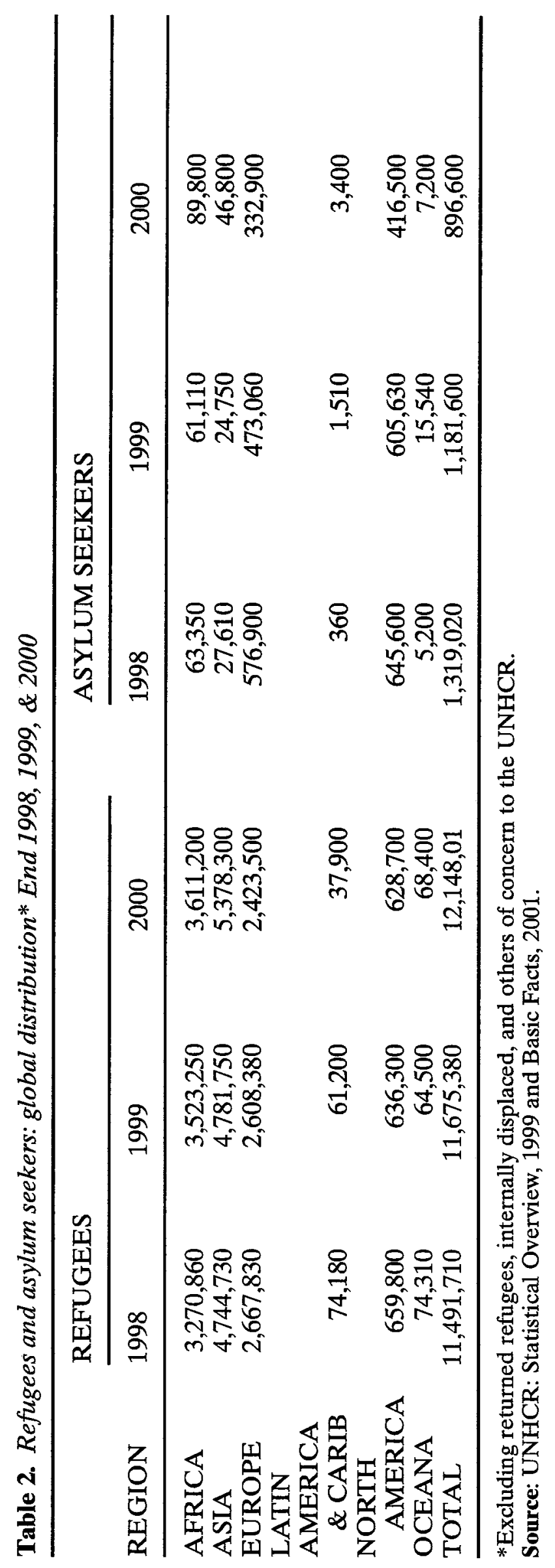


predicted that 'Non-western civilizations will continue to attempt to acquire the wealth, technology, skills, machines and weapons that are part of being modern. They will also attempt to reconcile this modernity with their traditional culture and values' (ibid. p. 49).

In emphasizing the 'East-West' threat, Huntington grossly oversimplified the situation. While not under-estimating the dangers of confrontation between Islamic fundamentalism and Western secularism, it is evident that the danger of intra-cultural and inter-religious conflict is at least as great within continental and state boundaries as between them. External intervention in civil wars and other internal crises, whether by NATO, the UN, or Corporations using mercenary armies, often spreads the conflict to neighbouring countries, leading to mass movements of displaced persons and refugees. Such intervention may be limited to 'peace- keeping' functions, or they may involve punitive action designed to 'punish' terrorism, or prevent further humanitarian disasters. Whether successful or not, such intervention further implicates other states. ${ }^{2}$ Those on the immediate borders of the country in turmoil bear the brunt of population displacement.

Ethno-religious wars in the Indian subcontinent, and elsewhere in Asia, together with ethnic conflicts in Africa, the former Soviet Union, and the Balkans, have already killed millions. The possibility of major confrontations between states possessing nuclear weapons, or the capacity to manufacture them cannot be ruled out. However, smaller regional conflicts, with or without nuclear weapons, could be more important than so-called 'civilizations' in determining the shape of things to come. The most intense conflict is likely to occur when rapid economic, political, social and environmental changes occur simultaneously, as is the case in many parts of Africa, the Middle East and Asia today. The very speed of these transitions generates a high degree of insecurity and fear. Considering the rise of forced migration in subSaharan Africa, Findley (2001, p. 279) notes that 'the root causes of armed conflicts are often economic, involving a struggle to gain control over limited, precious economic resources. Countries with dismal and deteriorating economic situations, rising unemployment, rampant inflation, and declining living standards are particularly at risk. for political chaos, complex emergencies and forced migration'. In the contemporary world system there has been a progressive de-territorialization of cultures, and an increase in hybridization (Pieterse 1995). This process is resisted by those who have a nostalgic attachment to a simpler era in which ethno-religious communities could retain their autonomy, or remain isolated from the impact of globalization and mass communications. In some regions of the world, theocratic forms of governance have once again gained power, as they did in the Middle ages. Religious conformity is then enforced by the state, and wars are ideologically justified in the name of religion. Only, this time, it is not just 
Christianity versus Islam (although that continues to be one source of conflict), but rather religious fundamentalism versus secularism and liberalism, that are at ideological loggerheads. The conflict is evident, both within and between societies, whether their cultural traditions are rooted in Christianity, Judaism, Islam, Hinduism, Sikhism, Buddhism, Shintoism, Confucianism, or some other tradition. The modernization process forces these societies to adopt a secular, materialistic faith in technology and trade. At the same time they must combat reactionary movements which are determined to reassert a strictly orthodox conformity to more traditional religious values. The postmodern dilemma is that exposure to all these opposing ideologies through mass communications, and the so-called 'information super-highway', generates an anomic condition.

When ethno-linguistic differences combine with those of religion or 'race', and coincide with economic differentials, the potential for conflict is exacerbated. Population pressures and environmental crises serve as intervening variables, increasing the probability of conflict (Horsman and Marshall 1995). Various actions can serve as precipitating events which lead to the greater politicization of ethnicity and the intensification of nationalist violence. They include collapse of an authoritarian regime, the death of a leader, rivalry between power elites, or evidence of atrocities committed by one side or another (Frye 1992, p. 623). Giddens (1994, p. 245) notes 'Wherever fundamentalism takes hold, whether it be religious, ethnic, nationalist or gender fundamentalism, degenerate spirals of communication threaten', leading to a vicious circle of animosity and xenophobia.

As Giddens states globalization produces not just extensional but intensional change, which leads to feelings of powerlessness and alienation. He points out that high consequential risks associated with contemporary nuclear technology and environmental crises, create a 'survivor' mentality, and fears of 'engulfment', or extermination (Giddens 1991, pp. 192-3). In its pathological form this involves a search for dominance, and fantasies of omnipotence, only too evident among some fanatical leaders, who play on people's fears, waging modern 'crusades' against potential enemies. Such conflicts generate further reactive migration.

\section{Conclusion}

At the beginning of the twenty-first century, we are bound to ask 'what is the role of the state in this new world order?' The locus of power in this global system is shifting from states to transnational corporations. Many of these corporations have wealth and resources that far exceed those of many member states of the United Nations. The role of transnational corporations in the future will be critical, if the positive benefits 
of globalization are to be realized,and its negative effects minimized. Protesters, violent or peaceful, at meetings of the WTO, the IMF, and similar bodies, have drawn attention to the harm that globalization may do. It remains to be seen what lessons are learned, and whether constructive solutions will be found to global warming and Third World economic development,

Rapidly changing political, economic and social conditions, linked to the impact of globalization, give rise to feelings of uncertainty and threaten traditional sources of collective identity. The rationale for maintaining the boundaries of existing states, and the political institutions that sustain them are undermined. The countries of eastern and central Europe are drawn into the orbit of the EU, even when they are not full members. Similarly, the North American Free Trade Agreement brings Canada and Mexico ever closer to the United States (Lusztig and James 1996; Courchene et al. 1998). Transnational corporations dominate the economy, while hegemonic cultural influences penetrate the media world-wide, through magazines, television and the internet. The traffic is not limited to exchanges of goods or information, but includes the smuggling of arms and people across frontiers. There is growing collaboration among police and immigration authorities to interdict such movements. The pressures which bring states closer together also generate opposition and reactive movements.

In the new millennium, the postmodern potential for disintegration and fragmentation cannot be ignored (McLellan and Richmond 1994). New forms of 'anomie' are already evident as politicians and religious leaders lament a breakdown in family and community values. Globalization generates serious risks, including apocalyptic visions of nuclear catastrophe, or total environmental collapse, as well as economic insecurity, heightened competition and fear of 'outsiders'. These are precisely the conditions likely to lead to greater ethnic conflict and overt racism. One of the ironies of a multicultural world is that, as diversity increases, so does the temptation to impose uniformity. On the one hand, majorities and formerly dominant classes feel threatened by the rapid social and cultural changes that undermine their hegemony. They would like to exclude people and ideas that threaten their sense of security. On the other hand, newly empowered minorities would like to impose their own agenda. As we have seen in places such as Yugoslavia and Indonesia, the empowerment of minorities and the achievement of independence are no guarantee of freedom of speech, or greater tolerance of diversity.

However, human beings are not helpless in the face of these contingencies. Institutional transformation can take place, peacefully and constructively, if there is a vision that comprehends ideals of equality, self-actualization and a positive response to the needs of local communities (Giddens 1991, 1994, 1999). Such positive outcomes will not be 
achieved by coercion. There must be a more constructive and creative response. Much has been written recently about a 'Third Way', that is, a political agenda that eschews the extremes of Communism or radical socialist policies, on the one hand, and unrestrained free market capitalism, on the other. The problem with this policy agenda, in practice, is that it incorporates contradictory values, its programme sets incompatible goals and the means advocated, in pursuit of these goals, are sometimes inappropriate. For example, Giddens (1998) lists 'cosmopolitan pluralism' among the 'third way' values; and 'cosmopolitan democracy' as well as the 'cosmopolitan state' among a list of programmatic items. He admits (p. 136) 'Cosmopolitanism and multiculturalism merge around the question of immigration. A cosmopolitan outlook is the necessary condition of a multicultural society in a globalizing order'. He regards Germany is a test case for cosmopolitan nationalism in the context of Europe. However, the European Union is guarding its borders and reinforcing immigration controls. In Britain, under New Labour, there is legislation designed to make it more difficult for asylum seekers to enter. 'Third Way' advocates claim to be opposed to social exclusion, which is equated with inequality; but exclusion is being practised in the name of preserving the privileges of those who enjoy the benefits of a 'welfare state'. Asylum seekers and so-called 'economic migrants' are the new under-class (when they are not actually deported, or refused entry altogether).

As Zygmunt Bauman notes, in his discussion of globalization, there is a huge gulf between the cosmopolitan elites, for whom cultural hybridization is a creative and emancipating experience, and the 'locals' (particularly in low income developing countries) who are culturally disempowered. He states. '.. the age of 'time/space compression, uninhibited transfer of information and instantaneous communication is also an almost complete communication breakdown between the learned elites and the populus' (Bauman 1998, p. 102). Bridging that gap, and incorporating the demographic majorities in the 'south' and the 'east' into the world system, is the great challenge of the twenty-first century. Major efforts will be needed to remove the enormous economic disparities between developed and developing countries, to bring an end to the global 'arms bazaar', and to ensure the full implementation of human rights legislation as applied to migrant workers and to refugees.

What are the policy implications of the above discussion? First and foremost, every effort must be made to ensure that the economic benefits of globalization are spread more equitably and that inequalities between countries, regions and continents are reduced, rather than increased, by the removal of barriers to trade. The new global division of labour must benefit the developing world, as well as those who are already wealthy. Secondly, the exploitation of resources, and the phenomena associated with global warming, should be contained in such a way that their 
negative consequences, and the environmental devastation that they have created in the past, are prevented and repaired.

Thirdly, cross-border population movements should be facilitated through bilateral and multilateral agreements that ensure reciprocity in all dimensions of human rights. As a first step, the ratification of the ILO draft 'Convention on the Protection of the Rights of all Migrant Workers and Members of their Families', by all industrialized countries, is important. This would go a long way towards removing some of the abuses currently associated with the employment of temporary workers (Bohning 1991, 1999). Fourthly, as recommended by the 'Commission on Global Governance', there should be 'more comprehensive institutionalized co-operation', or multilateral management of international migration. The positive benefits of migration must be recognized. Rather than imposing restrictions that only encourage clandestine migration, governments must facilitate temporary and permanent cross-border movements (Commission on Global Governance 1995, p. 207). Finally, governments must promote a sense of civic pride and citizenship while, at the same time, promoting knowledge and understanding of the world system, or 'global neighbourhood', to which we all belong. This calls for 'a common commitment to core values that all humanity could uphold: respect for life, liberty, justice and equity, mutual respect, caring and integrity' (ibid p. 336).

\section{Acknowledgements}

This is a revised version of a Senior Scholar lecture given at York University, Toronto. The author is indebted to referees for helpful comments on an earlier draft.

\section{Notes}

1. Care must be taken in the interpretation of population estimates and projections. Low, medium and high projections of global population totals, and their regional distribution, depend on a number of assumptions concerning fertility, mortality and net migration. There is necessarily a wide margin of error in such estimates. Similarly, as the UNHCR (1999, pp. 3-4)) report on 'Refugees and others of concern to UNHCR' explains, the quality of data on refugees is subject to rapid flux due to emergency situations, fluidity of movement and the difficulty of record keeping. Estimates of tourist movements, business travel, economic migration, clandestine movements, and migration precipitated by environmental catastrophes are all approximations. Not all such movements cross state boundaries. Many people internally displaced by the building of dams, other environmental crises and by urbanization and industrial development are not statistically recorded. However, large-scale internal migration can have international implications, and may generate intervention by UN agencies, and/or governmental and non-governmental organizations.

2. This article was written before the terrorist attacks in New York and Washington. The immediate reaction, by the American and other governments, was to demand 
a tightening of security at airports, and at all borders. The number of people fleeing Afghanistan escalated. The long-term consequences of these atrocities remain to be determined.

\section{References}

BAUMAN, ZYGMUNT 1998 Globalization: The Human Consequences, Cambridge: Polity Press

BLAIR, TONY and AMATO, GIULIANO 2001 'Closing Europe's back door', The Observer, 4 February, p. 31

BOHNING, R. 1991 'The ILO and the new Convention on migrant workers: the past and the future', International Migration Review, vol. 24, no. 4, pp. 698-709

1999 'Protection, International Norms and the Migrant Workers standards', paper presented at ILO Asian-Pacific Regional Forum

CASTELLS, MANUEL 1996 The Rise of Network Society, Oxford: Blackwell

1997 The Power of Identity, Oxford: Blackwell

1998 The End of Millennium, Oxford: Blackwell

CHIMNI, B. S. 2000 Globalisation, Humanitarianism and the Erosion of Refugee Protection, Oxford: Refugee Studies Centre, Queen Elizabeth House

COMMISSION ON GLOBAL GOVERNANCE 1995 Our Global Neighbourhood, Oxford: Oxford University Press

CORNWELL, G. H. and STODDARD, E. W. (eds.) 2001, Global Multiculturalism: Comparative Perspectives on Ethnicity, Race, and Nation, New York: Rowman \& Littlefield

COURCHENE, T. J. et al. 1998 From Heartland to North American Regional State: the Social Fiscal and Federal Evolution of Ontario, Toronto: University of Toronto Press, Faculty of Management

COZIC, C. P. et al. eds. 1994 Nationalism and Ethnic Conflict, San Diego, CA: Greenhaven Press

CUMMING, P. A., et al. 1989 Access! Task Force on Access to Trades and Professions, Toronto: Ministry of Citizenship

FINDLEY, S. E. 2001 ' Compelled to move: the rise of forced migration in Sub-Saharan Africa', in M. A. B. Siddique (ed.) International Migration into the 21st Century, Cheltenham UK. \& Northhampton MA: Edward Elgar

FRYE, TIMOTHY 1992 'Ethnicity, sovereignty and the transitions from non-democratic rule', Journal of International Affairs, vol. 45. No. 2, pp. 598-623

GHOSH, BIMAL 1998 Huddled Masses and Uncertain Shores: Insights into Irregular Migration, The Hague: Martinus Nijhof

GIDDENS, ANTHONY 1985 The Nation State and Violence, Cambridge: Polity Press

1990 The Consequences of Modernity, Cambridge: Polity Press

1991 Modernity and Self-Identity, Stanford: Stanford University Press

1994 Beyond Left and Right: The Future of Radical Politics, Cambridge: Polity Press

1998 The Third Way: Cambridge: Polity Press

1999 Runaway World: How globalisation is reshaping our lives, London: Profile Books HARRIS, NIGEL 1995 The New Untouchables: Immigration and the New World Worker, London: I.B. Taurus

HOMER-DIXON, T. F. 1999 Environment, Scarcity and Violence, Princeton, NJ: Princeton University Press

HOMER-DIXON, T. \& PERCIVAL, V. 1996 Environmental Scarcity and Violent Conflict: Briefing Book, Toronto: University College and AAASc

HORSMAN, M. \& MARSHALL, A. 1995 After the Nation-State: Citizen, Tribalism and the New World Disorder, London: Harper-Collins 
HUNTINGTON, S. P. 1996 The Clash of Civilizations and the Remaking of World Order, New York: Simon \& Schuster

KALDOR, MARY 1999 New and Old Wars: Organized Violence in a Global Era, Cambridge: Polity Press

LUSZTIG, M. \& JAMES, P. 1996 'Constitutional reform and the Free Trade Agreement: political entrepreneurship and the quest for re-alignment', International Journal of Canadian Studies, vol. 14, autumn, pp. 239-55

MCLELLAN, J. \& RICHMOND, A. H. 1994 'Multiculturalism in crisis: a postmodern perspective on Canada', Ethnic and Racial Studies, vol. 17, no. 4. pp. 662-83

OECD 1999 Trends in International Migration, 1998 Edition, Paris: OECD, SOPEMI

PIETERSE, JAN N. 1995 ' Globalization as hybridization', in M. Featherstone, S. Lash and R. Robertson (eds), Global Modernities, London: Sage, pp. 45-68

RICHMOND, ANTHONY H. 1967 Post-War Immigrants in Canada, Toronto: University of Toronto Press

1969 'Sociology of migration in industrial and postindustrial societies', in J. Jackson (ed.), Migration: Sociological Studies, Cambridge: Cambridge University Press

1984 'Ethnic Nationalism and Postindustrialism', Ethnic and Racial Studies vol. 7, no.

1, pp. 4-18

1993 'Reactive migration: sociological perspectives on refugee movements', Journal of Refugee Studies, vol. 6, pp. 7-24

1994 Global Apartheid: Refugees, Racism and the New World Order, Toronto: Oxford University Press, Canada

SALT, JOHN 2001 'The Business of International Migration', in M. A. B. Siddique (ed.) International Migration into the 21st Century, Cheltenham U.K. \& Northampton, MA: Edward Elgar

SASSEN, SASKIA 1998 Globalization and Its Discontents: Essays on the New Mobility of People and Money, New York: The New Press

SIDDIQUE, M. A. B. (ed.) 2001 International Migration into the 21st Century: Essays in honour of Reginald Appleyard, Cheltenham, U.K. \& Northampton, MA: Edward Elgar

STALKER, P. 2000 Workers Without Frontiers; The Impact of Globalization on International Migration, Boulder, CO: Lynne Rienner

UNITED NATIONS HIGH COMMISSION FOR REFUGEES 1999 Refugees and Others of Concern to the UNHCR,

1998 /1999 Statistical Overview, Geneva: UNHCR

2000 The State of the World's Refugees, Geneva: UNHCR

2001 Basic Facts < http: //www.unhcr.ch/cgi-bin/texis/vtx/ho.01.Oct.2001

VAN HORNE, W. A. 1997 Global Convulsions: Race, Ethnicity and Nationalism at the End of the Twentieth Century, New York: State University of New York Press

WALLERSTEIN, I. 1974 The Modern World System: Capitalist Agriculture and the Emergence of the European World, New York: Academic Press

Anthony H. Richmond is Emeritus Professor of Sociology, York University, Toronto.

ADDRESS Apt.710, 7811 Yonge Street, Thornhill, Ontario, L3T 4S3.

Canada. 